\title{
The Efficacy of High Performance Work Practices in the Middle East: Evidence from Algerian Firms
}

\author{
Boumediene Ramdani, Business School, University of Exeter, Exeter, UK \\ Kamel Mellahi, Warwick Business School, University of Warwick, Coventry, UK \\ Cherif Guermat, Bristol Business School, University of the West of England, Bristol, UK \\ Rabah Kechad, L'école Supérieure de Commerce, Alger, Algeria
}

\begin{abstract}
Although there is developing evidence on the effectiveness of global HRM best practices in emerging and developing economies, little is known about the efficacy of those practices in the Middle East. This study examines the impact of High Performance Work Practices (HPWP) on both employee and organizational outcomes in Algerian firms. The results of a firm-level survey show that while HPWP are positively associated with employee work attitudes and motivations, this effect is not converted into organizational level outcomes. The results are discussed, and implications for future research are offered.
\end{abstract}

Keywords: HPWP; HRM; Performance; Middle East; Algeria 


\section{Introduction}

Since they were proposed by Huselid (1995), scholarly interest in High Performance Work Practices' (HPWP) effects on employee and organizational outcomes has never waned (Combs, Liu, Hall and Ketchen, 2006; Posthuma, Campion, Masimova and Campion, 2013). The accumulated body of empirical evidence suggests that, on average, HPWP lead to a rise in productivity and overall organizational performance (Pfeffer 1994; Huselid, 1995; Delaney and Huselid, 1996; Combs et al., 2006; Sun, Aryee and Law, 2007) as well as employee outcomes such as high job satisfaction (Macky and Boxall, 2007; Wang, Yi, Lawler and Zhang, 2011). This body of research, however, has many limitations. Among the most intractable issues relating to HPWP has been a concern about their effectiveness in different institutional contexts given their Western lineage. In recent years, scholars have debated at great length whether HPWP are appropriate in emerging and developing countries (Collings, Demirbag, Mellahi, and Tatoglu, 2010; Horwitz, Kamoche and Chew, 2002; Sun, et al., 2007). One of the striking features of many of these debates is the implicit universality of HPWP. Horwitz et al. (2002: 1022), commenting on their (in)appropriateness in Asian and African contexts, noted that "there is a universalism implicit in much of the HPWP literature which may not stand the test of particularist attributes of different societal, industry and cross-cultural contexts”. The underlying assumption here is that the effectiveness of HPWP depends on their legitimacy; that is the perception that the practices are desirable, proper and congruent with employees' cultural values and norms (Suchman, 1995; Posthuma et al., 2013). However, the postulation that HPWP may not have the desired effects on employee and organizational outcomes in non-Western countries has remained largely untested. In the middle eastern context, with few exceptions (c.f. Collings et al.’s (2010) study of firms operating in Turkey), research to date on HRM best practices in the region has focused on their implementation (Al Shamsi, 2009), or the link between single aspects of HPWP such as high-involvement and organizational performance (Moideenkutty, Al-Lamki, and Murthy, 2011), or job satisfaction (Abdulla, Djebrani, and Mellahi, 2011). Thus, to date, we have very little empirical evidence on the link between HPWP and employee and organizational outcomes in a Middle Eastern context.

On the ground, firms do not wait for empirical evidence to accumulate before deciding which practices to implement. Firms operating in the Middle East are borrowing heavily from their Western counterparts. In recent years, these firms have embarked on a modernisation path which entails the adoption of global 'high performance' practices. This has resulted in 'heavy borrowing' of fashionable - often off the shelf - Western HR practices, 
particularly by large firms operating in the region (Murphy, 2002). Also, a number of foreign firms have flocked to the region in recent years (Mellahi, Demirbag and Riddle, 2011) bringing with them new global norms and practices. In addition to the potential impact of multinational firms, a number of European and US business schools and international consultancy firms have recently moved to the region and, not surprisingly, have been nudging local firms to adopt international best practices. Given the adoption of HPWP by firms in the Middle East, several scholars have recently called for research on the effectiveness of HPWP in the region (Al Shamsi, 2009; Mellahi, Demirbag, Collings, Tatoglu, and Hughes, 2013). Accordingly, in this paper, we contribute to the debate regarding the efficacy of HPWP by focusing on their association with employee and organizational outcomes in a Middle Eastern country, Algeria.

Algeria is a particularly interesting context for this study. Like other Middle Eastern countries, it is characterised by high power distance, strong collectivist tendencies (Calza, Aliane, and Cannavale, 2010), high uncertainty avoidance, and low performance orientation (Ralston, Egri, Riddle, Butt, Dalgic and Brock, 2012), which could, as will be discussed later, potentially limit the effects of HPWP. Also, since the late 1990s, the HR function has been significantly reformed and, as a result, firms in Algeria have been experimenting with Western best practices. Prior to that, HRM in Algeria was purely an administrative function with little emphasis on the management of HR and little attention was paid to individual and organizational outcomes (Yanat and Scouarnec, 2006). The HR function in Algeria has evolved over five major periods (Meziane, 1997). After 130 years of occupation, Algeria got its independence from France in 1962 and was left with a poorly skilled and largely uneducated population. The HR function then focused primarily on filling the gaps left by the departing French managers and bureaucrats. In the 1970s, the HR role changed to support the national socialist industrial development program by creating training centres to address severe skill shortages. The following decade was marked by major reforms which gave stateowned firms full autonomy. As a result, the HR function took on the development of job descriptions and the administration of personnel tools. In 1990, a significant reform of employment regulation was initiated with the introduction of the 90-11 Act (Boutaleb, 2012). This act marked the transition from a centrally controlled system to a 'liberal system' of employment that was more considerate of firms' social and economic realities. In the 2000s, the central government loosened its grip on the management of firms operating in Algeria. Consequently, Algerian firms started experimenting with HR best practices such as performance-related pay where premiums were paid for productivity. This makes Algeria an 
interesting context for examining the effectiveness of HPWP in the Middle East. Compared with other Middle Eastern countries, Algeria is perhaps the least studied and therefore little is known about how firms operate in it. In this study, we develop and test five hypotheses linking five best practices, namely investment in employee training and development, employee empowerment, performance related compensation, competence related performance appraisal, and merit related promotion, with employee and organizational outcomes. These practices are among the most studied HRM best practices (c.f. Fey, Bjorkman, and Pavlovskaya, 2000, p. 3; Collings et al., 2010, pp. 2592-2593).

This study departs from the dominant literature on HRM in the Middle East in a significant way. While current research (c.f. Budhwar and Mellahi, 2006, 2007; Afiouni, Karam and El-Hajj, 2013) provides useful insights into the dominant features of Middle Eastern HRM models, it remains silent about performance implications of HRM practices. This study helps close this gap by focusing on the performance implications of HRM best practices in Algerian firms.

\section{HRM Practices, Context, and Organizational Outcomes}

Employees’ performance has implications for a firm's performance (Huselid, 1995, Guest and Conway, 2011; Huselid, Jackson, and Schuler, 1997; Wright, McCormick, Sherman and McMahan, 1999; Bowen and Ostroff, 2004; Wall and Wood, 2005). The link between HRM practices and performance is context specific (c.f. Aycan, 2005). In particular, research has yet to determine which HRM best practice is more effective in which context (Fey, Morgoulis-Jakoushev, Park, and Bjorkman, 2009). For instance, Tsai's (2006) study of Taiwan's semiconductor design firms failed to provide support for the assertion that HPWP is associated with organizational outcomes. Similarly, a recent meta-analytic review reported that the magnitude of HPWP-performance relationship differs substantially by country and region (Rabl, Jayasinghe, Gerhart, and Kuehlmann, 2011). Moreover, there are methodological differences in the degree to which some research tends to focus on a narrower range of HPWP, whereas other studies include a wider range of HPWP (c.f. Posthuma et al., 2013). Thus, we still need to have a more complete picture of the interaction between HRM best practices and organizational performance in emerging and developing countries (Delery and Doty, 1996; Wood, 1999; Wall and Wood, 2005). Our study intends to contribute to this literature by examining the efficacy of HPWP in Algerian firms. 


\section{Hypotheses development}

In this paper, we consider five HPWP that are based on Fey et al.'s (2009) list of HRM best practices, and have been used extensively in previous studies (c.f. Minbaeva, Pedersen, Bjorkman, Fey and Park, 2003; Collings et al., 2010). In particular, we examine the link between the five HPWP, namely, employee training and development, employee empowerment, performance-based compensation, competence-based performance appraisal, and merit-based promotion, and individual and organisational outcomes. Below we develop the hypotheses on the associations between these practices and individual and organizational outcomes in the Algerian context.

\section{Employee training}

Investments in employee training enhance the human capital of the firm (Becker, 1975). Extant research shows that a positive relationship exists between employee training and firm performance (c.f. Delaney and Huselid, 1996; Koch and McGrath, 1996). More specifically, monitoring and evaluating training, linking training to career option schemes have been linked to improved firm performance (Brown and Heywood, 2005; Pfeffer, 1994; Mathieu, Martineau and Tannenbaum, 1993). From employees’ perspective, availability of training is perceived as a signal of being valued by the firm, and that it cares about their career development (Noe, 1986; Keep, 1989). Thus, training generally results in enhanced employee commitment and work attitudes (Lowry, Simon, and Kimberley, 2002; Bartlett, 2001).

Algeria, like other middle-eastern countries, is characterised by low performance orientation (Calza et al., 2010) and strong collectivist tendencies (Ralston et al., 2012). Aycan (2005) suggests that a low performance orientation is negatively correlated with the level of investment in training and development activities (see also Wilkins, 2001). Therefore one could argue that the lack of investment in employee training and development is likely to make employees more appreciative of training opportunities, which may subsequently lead to higher employee performance in employee work-related behaviours and enhance the organization's ability to attract, retain and motivate employees (Dysvik and Kuvaas, 2008). As put by Dysvik and Kuvaas (2008, pp.140-141) "high levels of training opportunities may be regarded as social exchanges between employer and employees ... (and) are associated with social exchange relationships that create feelings of employee obligation. Employee obligation, in turn, influences employees to benefit the organization through behaviors that exceed minimal requirements of employment”. Based on this, we propose that: 
H1: Employee training is positively associated with (a) employee performance; and (b) business performance.

\section{Employee empowerment}

Empowerment enhances firm performance by motivating employees to "work harder and more flexibly" thereby reducing the "costs of supervision and other indirect costs" (Birdi et al., 2008, p.471). Also, empowerment is expected to enhance employees' skills and abilities by involving them in decision making (Collings et al., 2010). Although a number of studies question the efficacy of empowerment in high power distance societies (Humborstad, Humborstad, Whitfield, and Perry, 2008), we posit that it has a positive impact on both employee and organizational level outcome in Algerian organisations for three reasons. First, Algeria has a long history of 'self-management' practices where employees were expected to be heavily involved in the management of their organizations (Clegg, 1972; Nellis, 1977; Branine, 2006; Branine, Fekkar, Fekkar, and Mellahi, 2008). Although officially the selfmanagement practice has been abandoned, its legacy remains. Second, given the recent Islamic revival in Algeria, employees may expect managers to involve them in the decision making process according to the Islamic Shura - consultation - principle (Mellahi and Budhwar, 2010). Third, given the widely reported management incompetency in Algeria, organizations that involve employees in the decision making process may perform better than organizations that concentrate the decision making powers in the top management team. These arguments lead us to the following hypothesis:

H2: Employee empowerment is positively associated with (a) employee performance; and (b) business performance.

\section{Performance-based compensation}

Compensation decisions play an important role in motivating employees (Guest, 1997). Generally, well designed compensation systems that link compensation schemes to organizational performance often enhance employee performance (Gomez-Mejia and Wiseman, 1997; Becker and Huselid, 1998), and subsequently lead to higher organizational performance (Gomez-Mejia and Wiseman, 1997). Although the association between performance-based compensation and employee and organizational performance are more pronounced in high-performance oriented cultures (Aycan et al., 2005), several recent studies 
(c.f. Mellahi et al., 2013; Gurbuz and Mert, 2011; Wang, et al., 2011) found that performance-based compensation has a positive impact on both individual and business performance in non-Western countries. Thus, we propose the following hypothesis:

H3: Performance-based compensation is positively associated with (a) employee performance; and (b) business performance.

\section{Competence-based performance appraisal}

Performance appraisal is an objective, rational, and systematic way for firms to manage the performance of their workforce (Chiang and Birtch, 2010). Effective performance appraisal systems can facilitate the identification of individual performance levels and individual skill gaps that could be addressed through training (Locke, Latham and Smith, 1990). Without a valid performance appraisal system in place, it would be difficult to accurately distinguish between good and poor performers, allocate rewards equitably and effectively, or communicate work expectations and motivate desired performance outcomes (Porter and Lawler, 1968). However, what constitutes 'good performance' is culture-bound (Aycan 2005). Specifically, effective performance evaluation in individualistic cultures tends to be based on performance criteria that are more objective, quantifiable, and observable (Harris and Moran, 1996). Examples include employee productivity, timeliness, quantity of outputs, and job-specific knowledge, and proficiency (Aycan, 2005). In contrast, in collectivistic cultures performance appraisal is more subtle and focuses on soft issues such as loyalty to the in-group which is often valued more than quantifiable performance measures such as productivity (Aycan, 2005). High-performing employees standing out in the group run the risk of being ostracized as this may disturb group harmony and invoke resentment (Kovach, 1995; Vallance, 1999). Thus, we propose the following:

H4: Competence-based performance appraisal is negatively associated with (a) employee performance; and (b) business performance.

\section{Merit-based promotion}

Promoting employees from within the firm is likely to provide a strong motivation for employees to work harder (Pfeffer, 1994; Lepak and Snell, 1999). When employees believe that promotion decisions are made based on their performance results, they are likely to be more motivated than employees whose promotion decisions are based on other factors such 
as personal relationships and seniority (Fey et al., 2009). While promotion decisions are mainly based on merit in high performance-oriented cultures, in-group favouritism is likely to play a big part in collectivistic cultures where promotion criteria include seniority, loyalty and good interpersonal relationships with superiors (Aycan, 2005; Schaubroeck and Lam, 2002). Mellahi and Frynas (2003, p.74) reported that practices such as merit-based promotion "are alien and diametrically opposed to prevailing work values and norms in Algeria" and often lead to "internal inconsistency" with existing HRM policies and practices. Thus, we posit that given that merit-based promotion goes against the culture grains in Algeria, which emphasizes seniority over merit, we suggest the following hypothesis:

H5: Merit-based promotion is negatively associated with (a) employee performance; and (b) business performance.

\section{Research Methods}

\section{Sample}

A convenient snowballing approach was used in this study. This is because, as with most Middle Eastern countries, firm-level surveys are extremely difficult in Algeria. Also, mailed surveys yield a very low response rate. ${ }^{1}$ We obtained a total of 86 questionnaires but discarded five questionnaires because of missing data. The questionnaire was translated into Arabic and French, and was validated for use in the Algerian context. This study followed the conventional forward-then-back translation approach taking into account local culture and dialect considerations when establishing conceptual equivalence between English, Arabic and French versions of the instrument (Chen and Bates, 2005). The main challenge was to maintain the meaning and the psychometric properties of the original instrument. Two experts fluent in English, Arabic and French were involved in the translation process. A pilot study was conducted with a number of managers which led to minor changes to some wordings. The questionnaire was administered directly by the authors.

\footnotetext{
${ }^{1}$ Initially, the sampling frame was drawn from the Annuaire des Entreprises Algerienne which contains 6904 large firms. The names and addresses of these companies were obtained from the same source. A random sample of 300 companies was drawn from this list and questionnaires were sent to HRM managers within these companies. After one reminder only two responses were obtained. We were then obliged to use personal contacts to induce a higher response rate.
} 
In order to reduce potential common method bias problems, respondents were asked to answer the questionnaire in two separate sessions, separated by at least one day. In the first session, respondents filled the parts related to respondents' personal and company details as well as information related to performance items (dependent variables). In the second session, respondents answered the questions relating to HRM practices (independent variables). The distribution of respondents is shown in Table 1. Although it is difficult to check the representativeness of our sample because of the lack of reliable official statistics in Algeria, we used the most reliable national survey we could obtain, which was carried out by the Algerian Office Nationale des Statistiques (ONS, 2012). Because the ONS sample is vastly dominated by micro enterprises we only focus on firms with 10 or more employees. We added this information to Table 1 for firm size and sector. As shown, our sample matches more closely that of the ONS in terms of sectors of activities.

\section{INSERT TABLE 1 HERE}

\section{Operationalization of variables}

The questionnaire design adopted in this study is based on earlier work by Collings et al. (2010), Fey and Bjorkman (2001), Minbaeva et al. (2003) and Bjorkman, Fey and Park (2007). All dependent and independent variables are measured using multidimensional scales. Because of the possibility that these items reflect a limited number of underlying latent dimensions, we performed principal components analyses with 'Varimax' rotation to extract the underlying factors representing the various sets of HRM practices, employee-level performance and business performance. Varimax was chosen primarily because it leads to a simple structure and has been successfully used in obtaining factors for the purposes of regression (c.f. Hair, Black, Bain, Anderson and Tatham, 2006; Sels, 2002; Lechner, Frankenberger, and Floyd, 2010; Peccei and Rosenthal, 2001). ${ }^{2}$

Scholars have highlighted the limitations of relying on single measures of performance (Guest, 1997), and the over-reliance on financial performance measures, in isolation, as they do not capture the full impact of HRM on the overall performance of the organization (Collings et al., 2010). To capture the link between HRM practices and firm performance, Guest (1997) argues that scholars need to use a range of performance measures

\footnotetext{
${ }^{2}$ However, for robustness, we repeated all the computations using oblique rotation (Oblimin) instead of Varimax. The results are essentially unchanged, and are available from the authors upon request.
} 
at both individual and organizational levels. Following Collings et al. (2010)'s suggestion, we used three performance measures, namely financial performance, employee skills and abilities, and employee motivation and commitment. In so doing, our study assesses both ‘organizational performance’ as well as employees’ related outcomes.

While it is generally preferable to use objective measures to capture firm performance, such as sales growth or shareholder return, we use a perceptual measure for two reasons. First and most important, accounting and other firm-level data are not available to researchers in Algeria. Second, available objective data are hard to verify in countries such as Algeria. As a remedy, many scholars have recommended the use of multiple measures based on subjective assessment of respondents (Geringer and Hebert, 1991; Ariño, 2003). Notwithstanding the limitation of perceptual measures, previous research has demonstrated their validity and suitability in measuring firm performance, as they are highly correlated with objective measures of performance (Venkatraman and Ramajuman, 1986; Venkatraman, 1990; Geringer and Hebert, 1991). We therefore develop two performance measures:

(1) Employee Performance: this variable captures employee attitudes and motivation. Respondents were asked to rate the performance of their firm's employees relative to competitors in their respective industry on each of the following five criteria: motivation; organizational commitment; flexibility / adaptability; work effort; and work longer than required (Park, Mitsuhashi, Fey and Bjorkman, 2003). Respondents indicated their rating on a 5-point Likert-type scale, ranging from 'far below average' through 'average' to 'far above average'. In addition to these five items, which capture relative performance, another item was added to capture employee attitudes within the organization. Respondents were asked whether they strongly disagreed to strongly agreed (on a 5-point Likert scale) with the statement: "Our employees are always behaving in ways that help our company's performance” (Park et al., 2003). The scale has a Cronbach’s Alpha of 0.878. In order to find the dimensions reflected in these six employee-level performance items, we carried out a factor analysis. The initial solution gave a first Eigenvalue equalling 3.787, but the remaining Eigenvalues were substantially less than unity. This suggests that the six items are well represented by a single factor, which explains $63 \%$ of the variance of these items. All items load positively and highly on the extracted factor.

(2) Business Performance: respondents were asked to indicate on a 9-point Likert-type scale, ranging from 'bottom 10\%' through 'average 50\%' to 'top 10\%', how they rate their company's performance in the following dimensions: operating efficiency; quality; service; sales; profitability; market share; and new product development (the reliability of the scale 
seems satisfactory; Cronbach's Alpha $=0.870$ ). We use factor analysis to reduce the dimension for the seven firm performance items. The initial solution gave one highly significant factor (Eigenvalue $=3.989$ ) explaining $56 \%$ of the variance of these items. Although the second Eigenvalue is below unity (0.934), the second factor explains an additional $14 \%$ approximately. We therefore decided to extract two factors for the firm's business performance. As shown in Panel A of Table 2, four of the items capturing business performance cleanly load on one factor, and two of the remaining items cleanly load on a second factor. Based on the nature of each set of items, the first factor relate to the firm's 'operating performance', while the last three items relate to the firm's 'financial performance'.

The independent variables were measured as follows:

Employee training (Training) was measured by three items. The first two items are the average number of days, per year, of formal training for managerial and non-managerial employees respectively. The third item is a 5-point Likert scale question that asks whether respondents strongly disagree to strongly agree with the statement: “Our company places a great deal of importance on training”. However, reducing the dimension of these mixed items is not straightforward. ${ }^{3}$ As Quinn (2004) noted, factor analysis is only appropriate when the observed items are either all continuous or all ordinal. Given that the number of formal training days revealed by our respondents is approximate in any case, there is no significant loss of information in discretizing our continuous items. We therefore recoded the first two items into five categories (no training, 1 to 5, 6 to 10, 11 to 15, and 16 or more days respectively). The initial factor analysis suggests a single factor (Eigenvalue $=1.79$ ) that explains nearly $60 \%$ of the variation of these items. All three items load positively on the factor, but the third item is slightly less influential (with a loading of 0.51 against 0.86 and 0.89 for the first and second items respectively). The scale is fairly reliable with a Cronbach's Alpha of 0.66.

Employee empowerment (Empowerment) was measured by two items. Respondents were asked whether they agreed or disagreed with the following two questions: "Employee input and suggestions are highly encouraged", and "Employee input and suggestions are often implemented" (Collings et al., 2010). Their rating was on a 5-point Likert scale (highly reliable with a Cronbach's Alpha of 0.922). A single factor, with an Eigenvalue of 1.86, was

\footnotetext{
${ }^{3}$ We thank a referee for bringing this to our attention.
} 
found to explain almost 93\% of the variance of these items. The second factor is highly insignificant with an Eigenvalue of 0.14. Both items load highly on this factor.

Performance-based compensation (Compensation) was measured by two items: "Our compensation system is closely connected with the financial results of the company”, and “Our company uses performance-based compensation” (Bjorkman et al., 2007). However, given the low Cronbach's Alpha of 0.429, the results must be interpreted with caution. As in the previous case, the two items are well represented by a single factor (Eigenvalue $=1.305$ ), which explains $65 \%$ of the variance of these items.

Competence-based appraisal was measured by five items. The respondents were asked whether they agreed with the following five statements (on a 5-point Likert scale): "Formal appraisal exists for at least some occupations”; “Appraisal is conducted at least once a year”; “Appraisal is linked to pay”; “Appraisals are used for a non-financial purpose (e.g. feedback, behaviour change)"; and "Half or more of non-managerial occupations have performance formally appraised” (Ramsay, Scholarios, and Harley, 2000). The scale is highly reliable with a Cronbach Alpha of 0.811 . The factor analysis produces one clearly significant Eigenvalue (2.87). The second Eigenvalue is slightly above 0.98 , which we consider to be significant because it implies a contribution of about $20 \%$ to the total variance, and because the extracted component clearly loads on non-financial items and has therefore an unambiguous interpretation. Moreover, Wood, Tataryn, and Gorsuch (1996) found that overextraction generally leads to less error than under-extraction in Principal Component Analysis (PCA) with Varimax rotation.

Panel B of Table 2 shows a split across two factors as there is a clear difference between the first three and the last two items. The first factor reflects the first three aspects of appraisal: existence, frequency, and financial link (Financial Appraisal). The last two items load heavily on the second factor. Given that the items relate to non-financial and nonmanagerial purposes, it seems reasonable to assume that respondents value extending appraisal for purposes other than financial and to occupations other than managerial (Broader Appraisal).

Merit-based promotion was measured by four items. These are: "Qualified employees have the opportunity to be promoted to positions of greater pay and / or responsibility within the company"; and "Our company places a great deal of importance on the following factors when making promotion decisions: (i) merit; (ii) seniority; and (iii) good personal relationships" (Gardner, Wright and Moynihan, 2011). The scale showed insufficient reliability (Crobach’s Alpha $=0.588$ ). This low reliability may be due to our small sample. 
However, we suspect that the sensitive nature of the question representing the last item may have affected the reliability of this scale. Indeed, once we remove this item, the remaining scale of three items becomes highly reliable with an Alpha of 0.76 . However, as we argue below, this variable has a special importance in a Middle Eastern context. We therefore include it in the analysis and treat the results relating to it with caution.

Two factors are clearly important (both with Eigenvalues greater than 1). The two factors explain more than $76 \%$ of the variance of the four items (Table 2, Panel C). These two factors are clearly distinct. The first three items load positively on the first factor. All three items reflect the normal or 'merit' promotion practice (based on qualification, merit and seniority) in the first factor (Merit-Based Promotion). The second factor loads on a single item, which, in contrast to the first three items, reflecting a 'non-merit' practice of promoting on the basis of personal relationships (Non Merit-Based Promotion). Although this item is to a large extent an antithesis of HPWP philosophy, we introduced it for two main reasons. First, we needed to capture the association between what is widely reported to be a dominant practice in the Middle East and firm performance. Statistically, including such a variable helps mitigating potential omitted variable problem. Second, despite its negative direction, the inclusion of this item in the scale and the fact that it is extracted as a separate latent variable in the factor analysis lends credence to our measures.

In addition to the variables discussed above, a set of three variables were included in the model to control for possible extraneous variations:

Firm age (AGE) is measured by the number of years that the firm had been in business.

Firm size (LOGSIZE) is captured by the logarithm of the number of employees of each firm. Large firms have more resources available to them, and can therefore implement more sophisticated HRM systems.

Industry variation is controlled via industry dummies. Although there is not a single way of classifying the various types of industries, we selected six different industry types that we believe better represent the Algerian context: (1) Industrial and electrical (IND_ELEC); (2) Construction (CONSTR); (3) Manufacturing (MANUF); (4) Financial services (FIN_SERV); (5) Trade (TRADE); and (6) Other services (OTHERSERV). 


\section{Results and Analysis}

Table 3 shows descriptive statistics and correlation coefficients of all independent variables. The first seven variables are principal components and are therefore standardised by construction (zero mean and unit variance). Note that, also by construction, the appraisal and promotion factors are uncorrelated. Most bivariate correlations are either insignificant or low (the highest correlation is 0.502). Thus, multicollinearity is not an issue and is not expected to affect the results (Hair, et al., 2006).

\section{INSERT TABLE 3 HERE}

We test our hypotheses via a series of regressions for each of the three performance outcomes: employee performance; operating performance; and financial performance. The results are shown in Tables 4 to 6 respectively. Each table shows the partial contribution of each HRM practice to performance after controlling for firm age, size and sector. For each dependent variable, we estimated 8 models. Model 1 contains control variables only in order to gauge the partial contribution of each HRM practice in explaining performance outcomes. Models 2 through 7 include individual HRM practices, while Model 8 includes all independent variables. The results show that the F-statistics are mostly significant for employee performance, always significant for operating performance, and mostly insignificant for financial performance. This reflects the possibility that performance outcomes are heterogeneous, in the sense that both sets of control variables and HRM practices may have different impacts for different outcomes. Overall, the control variables have little explanatory power. Based on Model 1, the R-squares are 10\%, 17\% and 13\% for employee performance, operating performance and financial performance respectively.

The individual effects of hypothesized variables were tested using Models 2 to 7. Under this approach, for each set of hypotheses tested in this study, three are confirmed for employee performance, one for operating performance, and one for financial performance. For employee performance, the results show that all individual coefficients for training (H1), empowerment (H2), merit-based compensation (H3), financial appraisal (H4a), and meritbased promotion $(\mathrm{H} 5)$ are highly significant $(\mathrm{p}<0.01)$ and positively relate to employee performance. However, the broader appraisal coefficient is insignificant. This implies that hypotheses 1, 2, and 3 are strongly supported for employee performance, while both remaining hypotheses are rejected. For $\mathrm{H} 4$, the financial appraisal coefficient is significant but positive (H4a implies a negative sign), while the broader appraisal coefficient is 
insignificant. For the last hypothesis (H5) the coefficient associated with merit-based promotion is significant but positive (H5 implies a negative sign). We therefore conclude that there is no evidence to support our fourth and fifth hypotheses.

The results for operating performance are much weaker. Only empowerment (H2) is highly significantly and positively relate to operating performance. The merit-based promotion coefficient $(\mathrm{H} 5)$ is weakly significant $(\mathrm{p}<0.10)$. However, given that it is positive, it is evidence against H5. Thus, for operating performance, only $\mathrm{H} 2$ is strongly confirmed, while $\mathrm{H} 1$ and $\mathrm{H} 3$ to $\mathrm{H} 5$ are rejected. For financial performance, the results show that only two coefficients are significant, namely empowerment (H2) and merit-based promotion (H5). However, while empowerment has the expected sign, merit-based promotion has a positive rather than a negative sign. Thus, $\mathrm{H} 2$ is strongly supported while the remaining hypotheses are rejected.

The evidence for our hypotheses in relation to each of the three types of performances is summarised in Table 7.

\section{INSERT TABLES 4, 5, 6 and 7 HERE}

In the final regression (Model 8), we employ a full model to assess the potential dominance of one or more HRM practices on each of the performance measures. While the individual regressions (Models 1 to 7 ) demonstrate a one-to-one relationship, the full model represents a many-to-one relationship between HRM practices and performance outcomes. Multivariate regressions provide the marginal contribution of each independent variable given the contribution of other variables. It is therefore not surprising to find that a variable has explanatory individual power but no significant contribution when combined with other variables. It simply means that the insignificant variable has no additional contribution in explaining the variation of the dependent variable. Indeed, taken together, Model 1 to Model 8 reflect the standard recommended procedure for testing mediation (Baron and Kenny, 1986; Sun, et al., 2007). When comparing the individual and full models, many HRM practices' effects fade and become insignificant in the full model. Following standard practice, this indicates support for mediating influence of those practices that remain significant in the full model. With this in mind, we estimated the full model regressions (Model 8) by removing the control variables that were insignificant in the individual regressions. The full models show that, when assessing the joint effect of HRM practices, only two (in the case of employee 
performance and operating performance) or one (in the case of financial performance) practices suffice to explain most of the variability in the performance outcomes.

For employee performance, empowerment (H2) and merit-based promotion (H5) are highly significant while training is only significant at the $10 \%$ level. The remaining independent variables are insignificant. The marginal contribution of empowerment is more than twice as big as that of promotion. To check that the remaining variables do indeed have minimal contribution, we carried out a hierarchical regression. The (unreported) results show that adding these insignificant independent variables barely changes the R-square, worsens the adjusted R-square, and decreases both the value and significance of the F-statistic. ${ }^{4}$ Thus, as discussed earlier, the combined results from individual and full models support mediation of empowerment and merit-based promotion. For operating performance, the mediation changes, with empowerment being the only significant variable in the full model. As before, a similar analysis to the above (hierarchical regression) was carried out, confirming the dominance of empowerment as well as the possibility of mediation. Finally, for financial performance, empowerment also appears to have a mediating effect. Again, further analysis shows that all other independent variables have no additional explanatory value in explaining or predicting financial performance.

\section{Discussion}

In this study, we have explored the relationships between HPWP and employee and organizational outcomes in Algerian firms. HPWP initiatives encompass a variety of practices that are designed to provide employees with opportunities to participate in the decision making process, career development opportunities through extensive training, and reward high performance by linking incentives as closely as possible to individual performance. In return, HPWP would result in a substantial benefit for organizations by helping them attract, develop, and retain highly talented and motivated workforce that can, subsequently, help organizations become more effective and achieve competitive advantage (Huselid, 1995). Our primary aim in this paper is to assess the effectiveness of HPWP in the Middle East. We achieve this aim by two means. First, we explore how employees respond to HPWP in a Middle Eastern context, and second, we test the universality of the widely held assumption that HPWP are a source of competitive advantage through high organizational performance (Coff, 1997). The results of this study reveal that while HPWP are positively

\footnotetext{
${ }^{4}$ To stay within the word limit, we decided not to report the results in the paper. The results are available from authors upon request.
} 
associated with positive work attitudes, this is not always translated into organizational level outcomes.

With regards to employee outcome, measured by employee work attitudes and motivation, our findings show that providing employees with developmental opportunities through training, empowering them to participate in decision making, and linking reward to individual performance result in positive work attitudes. However, the assertion that meritbased appraisal and merit-based promotion are incongruent with prevailing Algerian values and local practices, and therefore, would lead to negative employees' outcomes is not supported. The significant positive associations between competence-based performance appraisal and merit-based promotion and employee performance cast doubt on the dominant view that linking appraisal and promotion with individual performance in societies high in power distance and high in collectivism, would lead to negative work attitudes. There are two plausible explanations for these results. First, one can infer that, in line with previous studies on countries characterised by high power distance and high collectivism (Michailova and Hutchings, 2006; Mellahi and Guermat, 2004; Giacobbe-Miller, Miller, Zhang and Victorov, 2003), Algerian employees are perhaps becoming low in power distance and more individualistic, and as a result have a strong reticence to particularistic practices. Second, although promotion based on personal connections is still dominant in Middle Eastern societies (Tlaiss and Kauser, 2011), employees often discount "the competency and morality" of individuals that use personal connections for career advancement and prefer merit-based performance management (Mohamed and Mohamad, 2011). Overall, the results give credence to previous research (c.f. Mendonca and Kanungo, 1996; Pfeffer, 1995) who argued for the universal validity of some core elements of 'best practices' HRM systems. This viewpoint posits that linking certain HRM practices such as performance to financial reward and appraisal, and linking employees’ performance closely to key performance criteria are universal best practices that have pan socio-cultural applicability. Further research investigating why Algerian employees react positively to the Western instrumental appraisal system rather than the typical relational Algerian system is highly warranted.

The results related to our assumptions on the associations between HPWP and organizational level outcomes are mixed. Training has insignificant associations with operating efficiency and financial performance. The insignificant link between training and operating efficiency could be due to the design of training programmes that do not account for efficiency, while the insignificant association with financial performance could be due to the cost of training. Our results lend credence to the arguments that training is often 
expensive and organizations tend not to benefit from it (Salas, Cannon-Bowers, Rhodenizer and Bowers, 1999; Wright and Geroy, 2001; Caudron, 2002) or that training is often not associated with financial performance because firms carry out training for reasons other than improving their bottom line (Alliger, Tannenbaum, Bennett, Traver and Shortland, 1997),

Empowerment is found to be significantly and positively associated with both operating performance and financial performance. As posited earlier, given management incompetence in Algeria, involving expert employees in the decision making would enhance operating efficiency. Also, in contrast to training, empowerment is not a costly practice, and therefore its benefits are not offset by its associated cost. Similarly, the results suggest that merit-based promotion leads to higher operating efficiency and better financial performance. Again, this practice does not carry significant costs of implementation which may offset the returns accruing to the firm from using such a practice.

Performance based compensation and appraisal are insignificantly associated with operating performance and financial performance. Our results show that performance based compensation and appraisal result in positive work attitudes. This, however, does not appear to be translated into higher operating efficiency and or stronger financial performance. The design of our study does not enable us to explain the mechanisms through which HRM practices and work attitudes manifest themselves at the level of organizational outcomes. In brief, our results suggest that while certain HRM practices may improve employee motivation and work attitudes, the link between HRM practices and performance measures at the organizational level is not straightforward in Algeria. This is because financial performance may be affected by non-market factors such as government support (Sun, Mellahi, and Wright, 2012), which have little to do with employees performance. To unpack this link, future research may explore how HRM practices affect work attitudes and how the latter translates into organizational level outcomes.

Our results on the combined effects of HPWP reveal that only two practices account directly for the effects on employees' performance, operating performance, and financial performance. Specifically, employees’ performance is directly linked to empowerment and merit-based promotion, with the former accounting for almost twice the effect of the latter. The remaining practices have indirect effects on employee outcomes. Moreover, empowering employees and promoting them based on their merit have a direct positive impact on both operating efficiency and financial performance. Our results leave us with a practical puzzle: given that HPWP are unambiguously good for employee attitudes and motivation, but not necessarily good for organizational level outcome, why would firms in the Middle East 
introduce such practices? We suggest that they should for two reasons. First, the practices are not negatively associated with organizational level outcomes. That is, our results do now show that HPWP are value destroying practices, and therefore implementing them does not detracts from profits. Second, HPWP lead to better work attitudes and motivation However, our results made it apparent that if a business case is to be advanced for HPWP in the Middle East, the link between their impact on employee outcomes and organizational performance requires close scrutiny. Our results also show that the strength and nature of the impact direct or mediated - differ between the studied practices. Therefore, developing the right bundle of HPWP requires an in-depth understanding of how each practice, and combination of practices, affects employee and organizational outcomes.

Although this exploratory study adds to our understanding of HPWP in the Middle East in general and in Algerian organizations in particular, it has several limitations. First, as with all single country research, the results of this study have to be interpreted with caution and may not be generalised to other Middle Eastern countries. Another important limitation lies in the sample size and type of organizations studied. Although our sample size is adequate for this study, the findings might vary with a larger sample. Also, our data is purposefully largely dominated by firms from the two most industrialised regions in Algeria - Central North and South. We have therefore overlooked potential regional differences in our study. Extending our sample would thus be interesting as it will allow us to account for possible regional differences. However, the main conclusions drawn in this paper are likely to remain. 


\section{References}

Abdulla, J., Djebrani, R., and Mellahi, K. (2011), 'Determinants of Job Satisfaction in the UAE: A Case Study of the Dubai Police', Personnel Review, 40, 126-146.

Afiouni, F., Karam, C.M., and El-Hajj, H. (2013), 'The HR Value Proposition Model in the Arab Middle East: Identifying the Contours of an Arab Middle Eastern HR Model', International Journal of Human Resource Management, 24, 1895-1932.

Alliger, G. M., Tannenbaum, S. I., Bennett, W., Traver, H., and Shortland, A. (1997), 'A Metaanalysis on the Relations among Training Criteria', Personnel Psychology, 50, 341-358.

Al Shamsi, A.R. (2009), 'Factors Affecting High Performance Work Practices: Two Case Studies in the United Arab Emirates', unpublished Ph.D. dissertation, University of Salford, College of Arts and Social Sciences.

Ariño, A. (2003), 'Measures of Strategic Alliance Performance: An Analysis of Construct Validity', Journal of International Business Studies, 34, 66-79.

Aycan, Z. (2005), 'The Interplay between Cultural and Institutional/ Structural Contingencies in Human Resource Management Practices', International Journal of Human Resource Management, 16, 1083-1119.

Baron, R,M., and Kenny, D.A. (1986), 'The Moderator-Mediator Variable Distinction in Social Psychological Research: Conceptual, Strategic, and Statistical Considerations', Journal of Personality and Social Psychology, 51, 1173-1182.

Bartlett, K.R. (2001), 'The Relationship between Training and Organizational Commitment: a Study in the Health Care Field', Human Resource Development Quarterly, 12, 325352.

Becker, G.S. (1975), Human Capital, A theoretical and Empirical Analysis with Special Reference to Education, New York: Colombia University Press.

Becker, E.B., and Huselid, M.A. (1998), 'High Performance Work System and Firm Performance: A Synthesis of Research and Managerial Implications', Research in Personnel and Human Resource Management, 16, 53-101.

Birdi, K., Clegg, C., Patterson, M., Robinson, A., Stride, C., Wall, T. and Wood, S. (2008), 'The Impact of Human Resource and Operational Management Practices on Company Productivity: A Longitudinal Study', Personnel Psychology, 61, 467-501.

Bjorkman, I., Fey, C.F., and Park, H.J. (2007), 'Institutional Theory and MNC Subsidiary HRM Practices: Evidence from a Three Country Study', Journal of International Business Studies, 38, 430-445.

Boutaleb, K. (2012). 'Les politiques des salaires poursuivies en Algérie: une quête contrariée d'efficience'. Colloque International Algérie: cinquante ans d'expériences de développement Etat-Economie-Société, Alger, 8-9 Décembre, http://www.creaddz.org/cinquante-ans/Communication_2012/BOUTALEB.pdf

Bowen, D.E., and Ostroff, C. (2004), 'Understanding HRM-Firm Performance Linkages: The Role of the "Strength" of the HRM System', Academy of Management Review, 29, 203-221. 
Branine, M. (2006), 'Human Resource Management in Algeria', in Human Resource Management in the Middle East, eds. P. Budhawar, and K. Mellahi, New York: Routledge, 250-272.

Branine, M., Fekkar, A. F., Fekkar, O., and Mellahi, K. (2008), 'Employee Relations in Algeria: A Historical Appraisal', Employee Relations, 30, 404-421.

Brown, M., and Heywood, J.S. (2005), 'Performance Appraisal Systems: Determinants and Change', British Journal of Industrial Relations, 434, 659-680.

Budhwar, P. and Mellahi, K. (2006), HRM in the Middle East, New York: Routledge.

Budhwar, P. and Mellahi, K. (2007), 'Introduction: Human Resource Management in the Middle East', International Journal of Human Resource Management, 18, 2-10.

Calza, F., Aliane, N., and Cannavale, C. (2010), 'Cross-Cultural Differences and Italian firms' Internationalization in Algeria: Exploring Assertiveness and Performance Orientation', European Business Review, 22, 246-272.

Caudron, S. (2002), 'Just Say No to Training Fads', Personnel Management, 56, 38-44.

Chen, H., and Bates, R.A. (2005), 'Instrument Translation and Development Strategies for Cross-Cultural Studies,' in Proceedings of the Academy of Human Resource Development, 693-700.

Chiang, F.F.T., and Birtch, T.A. (2010), 'Appraising Performance across Borders: An Empirical Examination of the Purposes and Practices of Performance Appraisal in a Multi-Country Context', Journal of Management, 47, 1365-1393.

Clegg, I. (1972), Workers' Self-Management in Algeria, New York: Monthly Review Press.

Coff, R.W. (1997), 'Human Assets and Management Dilemmas: Coping with Hazards on the Road to Resource-Based Theory', Academy of Management Review, 22, 374-402.

Collings, D., Demirbag, M., Mellahi, K., and Tatoglu, E. (2010), 'Strategic Orientation, Human Resource Management Practices and Organizational Outcomes: Evidence from Turkey', International Journal of Human Resource Management, 21, 2589-2631.

Combs, J., Liu, Y., Hall, A., and Ketchen, D. (2006), 'How Much Do High-Performance Work Practices Matter? A Meta-analysis of their Effects on Organizational Performance'. Personnel Psychology, 59, 501-528.

Delaney, J.T., and Huselid, M. (1996), 'The Impact of Human Resource Management Practices on Perceptions of Organizational Performance', Academy of Management Journal, 39, 949-969.

Delery, J.E., and Doty, D.H. (1996), 'Modes of Theorizing in Strategic Human Resource Management: Tests of Universalistic, Contingency, and Configurational Performance Predictions', Academy of Management Journal, 39, 802-835.

Dysvik, A., and Kuvaas, B. (2008), 'The Relationship between Perceived Training Opportunities, Work Motivation and Employee Outcomes', International Journal of Training and Development, 12, 138-157.

Fey, C.F., and Bjorkman, I. (2001), 'The Effect of Human Resource Management Practices on MNC Subsidiary Performance in Russia', Journal of International Business Studies, 32, 59-75. 
Fey, C.F., Bjorkman, I., and Pavlovskaya, A. (2000), 'The Effect of Human Resource Management Practice on Firm Performance in Russia', International Journal of Human Resource Management, 11, 1-18.

Fey, C.F., Morgoulis-Jakoushev, S., Park, H.J., and Bjorkman, I. (2009), 'Opening Up the Black Box of the Relationship between HRM Practices and Firm Performance: A Comparison of USA, Finland and Russia', Journal of International Business Studies, 40, 690-712.

Gardner, T.M., Wright, P.M., and Moynihan, L.M. (2011), 'The Impact of Motivation, Empowerment, and Skill Enhancing Practices on Aggregate Voluntary Turnover: The Mediating Effect of Collective Affective Commitment', Personnel Psychology, 64, 315-350.

Geringer, M.J., and Hebert, L. (1991), 'Measuring Performance of International Joint Ventures’, Journal of International Business Studies, 22, 249-263.

Giacobbe-Miller, J.K., Miller, D.J., Zhang, W., and Victorov, V.I. (2003), 'Country and Organizational-Level Adaptation to Foreign Workplace Ideologies: A Comparative Study of Distributive Justice Values in China, Russia and the United States', Journal of International Business Studies, 34, 389-406.

Gomez-Mejia, L.R., and Wiseman, R.M. (1997), 'Reframing Executive Compensation: An Assessment and Outlook', Journal of Management, 23, 291-374.

Guest, D.E. (1997), 'Human Resource Management and Performance: A Review and Research Agenda', International Journal of Human Resource Management, 8, 263276.

Guest, D., and Conway, N. (2011), 'The Impact of HR Practices, HR Effectiveness and a 'Strong HR System' on Organisational Outcomes: A Stakeholder Perspective', International Journal of Human Resource Management, 22, 1686-1702.

Gurbuz, S., and Mert, I.S. (2011), 'Impact of the Strategic Human Resource Management on Organizational Performance: Evidence from Turkey’, International Journal of Human Resource Management, 22, 1803-1822.

Hair, J.F., Black, W.C., Babin, B.J., Anderson, R.E., and Tatham, R.L. (2006), Multivariate Data Analysis (6th ed.), Upper Saddle River, NJ: Pearson.

Harris, P.R. and Moran, R.T. (1996), Managing Cultural Differences, Houston, TX: Gulf.

Horwitz, F.M., Kamoche, K., and Chew, I.K. (2002). 'Looking East: Diffusing High Performance Work Practices in the Southern Afro-Asian Context', International Journal of Human Resource Management, 13, 1019-1041.

Humborstad, S. I. W., Humborstad, B., Whitfield, R., and Perry, C. (2008), 'Implementation of empowerment in Chinese high power-distance organizations'. The International Journal of Human Resource Management,, 19, 1349-1364.

Huselid, M.A. (1995), 'The Impact of Human Resource Management Practices on Turnover, Productivity, and Corporate Financial Performance', Academy of Management Journal, 38, 635-672.

Huselid, M.A., Jackson, S.E. and Schuler, R.S. (1997), 'Technical and Strategic Human Resource Management Effectiveness as Determinants of Firm Performance', Academy of Management Journal, 40, 171-188. 
Katou, A.A., and Budhwar, P.(2006), 'Human Resource Management Systems and Organizational Performance: A Test of a Mediating Model in the Greek Manufacturing Context', International Journal of Human Resource Management, 17, 1223-1253.

Keep, E. (1989). 'Corporate Training: The Vital Component?' in New Perspectives on Human Resource Management, eds. J. Storey, London: Routledge.

Koch, M. J., and McGrath, R.G. (1996), 'Improving Labor Productivity: Human Resource Management Policies Do Matter’, Strategic Management Journal, 17, 335-354.

Kovach, R.C.Jr. (1995) 'Matching Assumptions to Environment in the Transfer of Management Practices', International Studies of Management and Organization, 24, 83-100.

Lechner, C., Frankenberger, K., and Floyd, S.W. (2010), 'Task Contingencies in the Curvilinear Relationships between Intergroup Networks and Performance', Academy of Management Journal, 53, 865-889.

Lepak, D.P. and Snell, S.A. (1999), 'The Human Resource Architecture: Towards a Theory of Human Capital Allocation and Development', Academy of Management Review, 24, 31-48.

Locke, E.A., Latham, G.P., and Smith, K.J. (1990), A Theory of Goal Setting and Task Performance, Englewood Cliffs, NJ: Prentice-Hall.

Lowry, D.S., Simon, A., and Kimberley, N. (2002), 'Toward Improved Employment Relations Practices of Casual Employees in the New South Wales Registered Clubs Industry', Human Resource Development Quarterly, 13, 53-70.

Macky, K., and Boxall, P. (2007), 'The Relationship between 'High-Performance Work Practices' and Employee Attitudes: An Investigation of Additive and Interaction Effects', International Journal of Human Resource Management, 18, 537-567.

Mathieu, J.E., Martineau, J.W., and Tannenbaum, S.I. (1993), 'Individual and Situational Influences on the Development of Self-efficacy: Implications for Training Effectiveness', Personnel Psychology, 46, 125-148.

Mellahi, K., and Budhwar, P.S. (2010), 'Introduction: Islam and Human Resource Management', Personnel Review, 39, 685-691.

Mellahi, K., Demirbag, M., Collings, D., Tatoglu, E., and Hughes, M. (2013), 'Similarly Different: A Comparison of HRM Practices in MNE Subsidiaries and Local Firms in Turkey’, International Journal of Human Resource Management, 24, 2339-2368.

Mellahi, K., Demirbag, M. and Riddle, L. (2011), 'Multinationals Strategies in the Middle East: Institutional Environment and Strategies', Journal of World Business, 46, 406410.

Mellahi, K., and Guermat, C. (2004), 'Does Age Matter? An Empirical Investigation of the Effect of Age on Managerial Values and Practices in India', Journal of World Business, 39, 199-215.

Mellahi, K., and Frynas, J. G. (2003), 'An Exploratory Study into the Applicability of Western HRM Practices in Developing Countries: An Algerian Case Study', International Journal of Commerce and Management, 13, 61-80. 
Mendonca, M., and Kanungo, R.N. (1996), 'Impact of Culture on Performance', International Journal of Manpower, 17, 65-69.

Meziane, M. (1997). Evaluation de la fonction ressources humaines en Algérie, Association Algérienne des Ressources Humaines (ALGRH), Algiers, http://www.fmrh.org/etudesetprojets/projet-agora/fonctionrhpaysmediterranee/29evolutionfonction-rhalgerie

Michailova, S., and Hutchings, K. (2006), 'National Cultural Influences on Knowledge Sharing: A Comparison of China and Russia', Journal of Management Studies, 43, 383-405.

Minbaeva, D., Pedersen, T., Bjorkman, I., Fey, C.F., and Park, H.J. (2003), 'MNC Knowledge Transfer, Subsidiary Absorptive Capacity, and HRM', Journal of International Business Studies, 34, 586-599.

Mohamed, A.A., and Mohamad, M.S. (2011), 'The Effect of Wasta on Perceived Competence and Morality in Egypt', Cross Cultural Management, 18, 412-425.

Moideenkutty, U., Al-Lamki, A., and Murthy, R. (2011), 'HRM Practices and Organizational Performance in Oman', Personnel Review, 40, 239-251.

Murphy, T.E. (2002), 'Market Forces and the Middle East's New Interest in HRM', Business Horizons, 45, 63-71.

Nellis, J.R. (1977), 'Socialist Management in Algeria', The Journal of Modern African Studies, 15, 529-554.

Noe, R.A. (1986), “Trainees’ Attributes and Attitudes: Neglected Influences on Training Effectiveness', Academy of Management Review, 11, 736-749.

ONS (2012), 'Premier Recensement Economique, Resultats Definitifs de la Premiere Phase', Office Nationale des Statistiques, Algiers, http://www.ons.dz/

Park, H.J., Mitsuhashi, H., Fey, C.F. and Bjorkman, I. (2003), 'The Effect of Human Resource Management Practices on Japanese MNC Subsidiary Performance: A Partial Mediating Model', International Journal of Human Resource Management, 14, 13911406.

Peccei, R., and Rosenthal, P. (2001), 'Delivering Customer-Oriented Behaviour through Empowerment: An Empirical Test of HRM Assumptions', Journal of Management Studies, 38, 831-857.

Pfeffer, J. (1994), Competitive Advantage through People, Boston, MA: Harvard Business School Press.

Pfeffer, J. (1995), 'Producing Sustainable Competitive Advantage through the Effective Management of People', Academy of Management Executive, 9, 55-69.

Porter, L.W., and Lawler, E.E. (1968), Managerial Attitudes and Performance, Homewood, IL: Richard D. Irwin.

Posthuma, R.A., Campion, M.C., Masimova, M., and Campion, M.A. (in press), 'A High Performance Work Practices Taxonomy Integrating the Literature and Directing Future Research', Journal of Management.

Quinn, K.M. (2004), 'Bayesian Factor Analysis for Mixed Ordinal and Continuous Responses’, Political Analysis, 12, 338-353. 
Rabl, T., Jayasinghe, M.M., Gerhart, B., and Kuehlmann, T.M. (2011). 'How Much does Country Matter? A Meta-Analysis of the HPWP Systems-Business Performance Relationship', in The Annual Meeting of the Academy of Management, San Antonio.

Ralston, D.A., Egri, C.P., Riddle, L., Butt, A., Dalgic, T., and Brock, D.M. (2012), 'An Exploration of Managerial Values in the Greater Middle East: Similarities and Differences across Seven Countries', International Business Review, 21, 480-492.

Ramsay, H., Scholarios, D., and Harley, B. (2000), 'Employees and High-performance Work Systems: Testing Inside the Black Box', British Journal of Industrial Relations, 38, 501-531.

Salas, E., Cannon-Bowers, J., Rhodenizer, L., and Bowers, C. (1999), 'Training in Organizations: Myths, Misconceptions, and Mistaken Assumptions', Research in Personnel and Human Resource Management, 17, 123-161.

Schaubroeck, J. and Lam, S.S.K. (2002), 'How Similarity to Peers and Supervisor Influences Organizational Advancement in Different Cultures', Academy of Management Journal, 45, 1120-1136.

Sels, L. (2002), 'More is Not Necessarily Better: The Relationship between the Quantity and Quality of Training Efforts', International Journal of Human Resource Management, 13, 1279-1298.

Suchman, M.C. (1995), 'Managing Legitimacy: Strategic and Institutional Approaches', Academy of Management Journal, 20, 571-610.

Sun, L.Y., Aryee S., and Law K.S. (2007), 'High Performance Human Resource Practices, Citizenship Behavior, and Organizational Performance: A Relational Perspective, Academy of Management Journal, 50, 558-577.

Sun, P., Mellahi, K., and Wright, M. (2012), 'The Contingent Value of Corporate Political Ties’, Academy of Management Perspectives, 26, 68-82.

Tlaiss, H., and Kauser, S. (2011), 'The Importance of Wasta in the Career Success of Middle Eastern Managers', Journal of European Industrial Training, 35, 467-486.

Tsai, C.J. (2006). 'High performance work systems and organizational performance: an empirical study of Taiwan's semiconductor design firms', International Journal of Human Resource Management, 17, 1512-1530.

Vallance, S. (1999), 'Performance Appraisal in Singapore, Thailand and the Philippines: A Cultural Perspective’, Australian Journal of Public Administration, 58, 78-86.

Venkatraman, N. (1990), 'Performance Implications of Strategic Coalignment: A Methodological Perspective’, Journal of Management Studies, 27, 19-41.

Venkatraman, N., and Ramanujam, V. (1986), 'The Measurement of Business Performance in Strategy Research: A Comparison of Approaches', Academy of Management Review, 11, 801-814.

Wall, T.D., and Wood, S.J. (2005), 'The Romance of Human Resource Management and Business Performance and the Case for Big Science', Human Relations, 58, 429-462.

Wang, S., Yi, X., Lawler, J., and Zhang, M. (2011). 'Efficacy of High-Performance Work Practices in Chinese Companies'. International Journal of Human Resource Management, 22, 2419-2441. 
Wilkins, S. (2001), 'International Briefing 9: Training and Development in the United Arab Emirates', International Journal of Training and Development, 5, 153-165.

Wood, S.J. (1999), 'Human Resource Management and Performance', International Journal of Management Reviews, 1, 367-413.

Wood, J.M., Tataryn, D.J., and Gorsuch, R.L. (1996), 'Effects of Under- and Overextraction on Principal Axis Factor Analysis with Varimax Rotation’, Psychological Methods, 1, 354-365.

Wright, C.P., and Geroy, D.G. (2001), 'Changing the Mindset', International Journal of Human Resource Management, 12, 586-600.

Wright, P.M., McCormick, B., Sherman, W.S., and McMahan, G.C. (1999), 'The Role of Human Resources Practices in Petro-Chemical Refinery Performance', International Journal of Human Resource Management, 10, 551-571.

Yanat, Z., and Scouarnec, A. (2006), Perspectives sur la GRH au Maghreb: Algérie-MarocTunisie, Paris: Vuibert. 
Table 1. Frequency Statistics of Respondents.

\begin{tabular}{|c|c|c|c|c|c|c|c|c|c|c|}
\hline & Category & Percent & Category & Percent & Category & Percent & Category & Percent & Category & Percent \\
\hline \multicolumn{11}{|c|}{ Respondent's Characteristics } \\
\hline Age & 21 to 29 & 8.6 & 30 to 39 & 22.2 & 40 to 49 & 38.3 & 50 or older & 30.9 & & \\
\hline Qualification & $\begin{array}{c}\text { Business/ } \\
\text { Management }\end{array}$ & 25.3 & $\begin{array}{l}\text { Humanities/ } \\
\text { Soc.Sciences }\end{array}$ & 30.4 & Engineering & 15.2 & $\begin{array}{c}\text { Medical/ } \\
\text { Biological Sciences }\end{array}$ & 2.5 & Other & 26.6 \\
\hline Managerial Level & $\begin{array}{l}\text { Upper-Level } \\
\text { Management }\end{array}$ & 43.2 & $\begin{array}{l}\text { Middle-Level } \\
\text { Management }\end{array}$ & 35.8 & $\begin{array}{l}\text { Lower-Level } \\
\text { Management }\end{array}$ & 21.0 & & & & \\
\hline \multicolumn{11}{|c|}{ Firm Characteristics } \\
\hline Firm Size & 50 or less & 25.9 & $51-200$ & 16.0 & $201-1000$ & 27.2 & $1001-10000$ & 21.0 & $10000+$ & 9.9 \\
\hline (ONS) & $10-49$ & $(76.3)$ & $50-249$ & $(19.0)$ & $250+$ & $(4.6)$ & & & & \\
\hline Firm Age & 10 or less & 24.4 & $11-20$ & 24.4 & $21-30$ & 24.4 & $31+$ & 26.9 & & \\
\hline Sector & Industry & 28.4 & Construction & 11.1 & Trade & 4.9 & Financial Services & 11.1 & Service & 44.4 \\
\hline (ONS) & & $(44.4)$ & & (20.5) & & (21.7) & & (13.2) & & (21.9) \\
\hline
\end{tabular}

$\mathrm{N}=81$. We use the Algerian Office of National Statistics (ONS) figures for entities that have 10 or more employees. The ONS sector definitions do not match ours exactly.

The firm age data provided by ONS is dominated by very small firms (1 to 9 employees), most of which were established after 2000 . 
Table 2. Results of Factor Analysis.

\begin{tabular}{|c|c|c|}
\hline \multirow[b]{2}{*}{ Panel A: Business Performance } & \multicolumn{2}{|c|}{ Factors and Factor Loading } \\
\hline & Operating Performance & Financial Performance \\
\hline Operating efficiency & 0.826 & 0.196 \\
\hline Quality & 0.823 & 0.304 \\
\hline Service & 0.864 & 0.178 \\
\hline Sales & 0.665 & 0.478 \\
\hline Profitability & 0.318 & 0.820 \\
\hline Market share & 0.437 & 0.547 \\
\hline New product development & 0.110 & 0.841 \\
\hline $\begin{array}{c}\text { Panel B: Competence-based appraisal } \\
\end{array}$ & Financial Appraisal & Broader Appraisal \\
\hline Formal appraisal exists for at least some occupations & 0.777 & 0.410 \\
\hline Appraisal is conducted at least once a year & 0.905 & 0.152 \\
\hline Appraisal is linked to pay & 0.901 & 0.086 \\
\hline Appraisals are used for a non-financial purpose (e.g. feedback, behaviour change) & 0.034 & 0.903 \\
\hline Half or more of non-managerial occupations have performance formally appraised & 0.386 & 0.673 \\
\hline & & Non-Merit Based \\
\hline $\begin{array}{c}\text { Panel C: Merit-based promotion } \\
\end{array}$ & Merit-Based Promotion & Promotion \\
\hline $\begin{array}{l}\text { Qualified employees have the opportunity to be promoted to positions of greater pay and/or } \\
\text { responsibility within the company }\end{array}$ & 0.796 & -0.247 \\
\hline Promotion is based on Merit & 0.866 & 0.010 \\
\hline Promotion is based on Seniority & 0.761 & 0.329 \\
\hline Promotion is based on good personal relationships & -0.005 & 0.957 \\
\hline
\end{tabular}

Note. The variables that were summarised by single factors (Employee Performance, Employee Training, Employee Empowerment, and Performance-based Compensation) are not shown in this table, but are explained fully in the text. 
Table 3. Descriptive statistics and correlation coefficients of independent variables.

\begin{tabular}{|c|c|c|c|c|c|c|c|c|c|c|c|c|c|c|c|c|}
\hline & Mean $s$ & S.D. & 1 & 2 & 3 & 4 & 5 & 6 & 7 & 8 & 9 & 10 & 11 & 12 & 13 & 14 \\
\hline 1. Training & 0.00 & 1.00 & 1 & & & & & & & & & & & & & \\
\hline 2. Empowerment & 0.00 & 0.98 & 0.13 & 1 & & & & & & & & & & & & \\
\hline 3. Compensation & 0.00 & 0.98 & 0.17 & $0.35^{* *}$ & 1 & & & & & & & & & & & \\
\hline 4. Financial Appraisal & 0.00 & 0.98 & $0.40^{* *}$ & $0.38^{* *}$ & $.41^{* *}$ & 1 & & & & & & & & & & \\
\hline 5. Broader Appraisal & 0.00 & 0.98 & -0.02 & $0.25^{*}$ & 0.02 & 0.00 & 1 & & & & & & & & & \\
\hline 6. Merit-Based Promotion & 0.00 & 0.98 & $0.25^{*}$ & $0.50^{* *}$ & $0.26^{*}$ & $0.37^{* *}$ & 0.10 & 1 & & & & & & & & \\
\hline 7. Non Merit-Based Promotion & 0.00 & 0.98 & -0.15 & $-0.25^{*}$ & -0.21 & -0.18 & 0.04 & 0.00 & 1 & & & & & & & \\
\hline 8. AGE & 0.00 & 1.00 & -0.05 & -0.02 & 0.05 & 0.06 & 0.16 & -0.13 & -0.04 & 1 & & & & & & \\
\hline 9. LOGSIZE & 6.04 & 2.31 & 0.18 & -0.10 & $-0.24^{*}$ & 0.00 & -0.02 & -0.13 & -0.02 & $0.26^{*}$ & 1 & & & & & \\
\hline 10. IND_ELEC & 0.09 & 0.28 & -0.01 & 0.07 & 0.05 & 0.01 & $.24^{*}$ & 0.05 & 0.15 & -0.15 & -0.07 & 1 & & & & \\
\hline 11. CONSTR & 0.11 & 0.32 & -0.06 & $-0.25^{*}$ & -0.06 & -0.19 & -0.01 & -0.14 & 0.05 & -0.16 & -0.13 & -0.11 & 1 & & & \\
\hline 12. MANUF & 0.20 & 0.40 & -0.13 & 0.07 & -0.01 & -0.12 & -0.10 & -0.12 & 0.03 & $0.24^{*}$ & 0.04 & -0.15 & -0.18 & 1 & & \\
\hline 13. FIN_SERV & 0.11 & 0.32 & 0.01 & -0.08 & -0.14 & 0.14 & 0.07 & 0.02 & -0.11 & 0.14 & -0.11 & -0.11 & -0.13 & -0.18 & 1 & \\
\hline 14. TRADE & 0.19 & 0.39 & -0.16 & 0.11 & 0.16 & 0.08 & 0.05 & -0.01 & 0.01 & 0.05 & -0.12 & -0.15 & -0.17 & $-0.24^{*}$ & -0.17 & 1 \\
\hline 15. OTHERSERV & 0.31 & 0.46 & $0.27 * *$ & 0.03 & -0.02 & 0.07 & -0.14 & 0.17 & -0.08 & -0.14 & $0.28^{*}$ & -0.21 & $-0.24^{*}$ & $-0.33^{* *}$ & $-0.24^{*}$ & $-0.32^{* *}$ \\
\hline
\end{tabular}


Table 4. Regression results (Employee Performance).

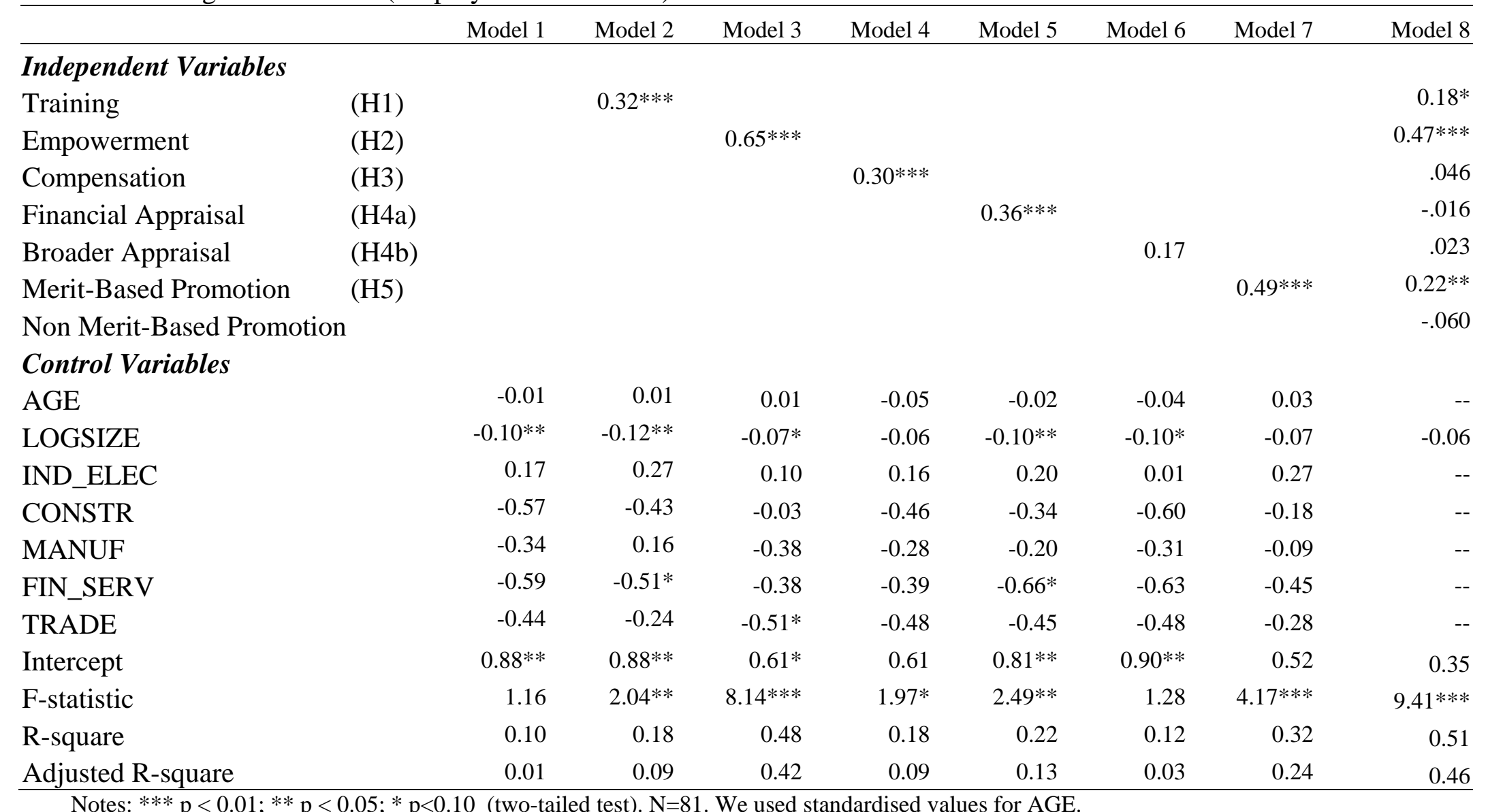


Table 5. Regression results (Operating Performance)

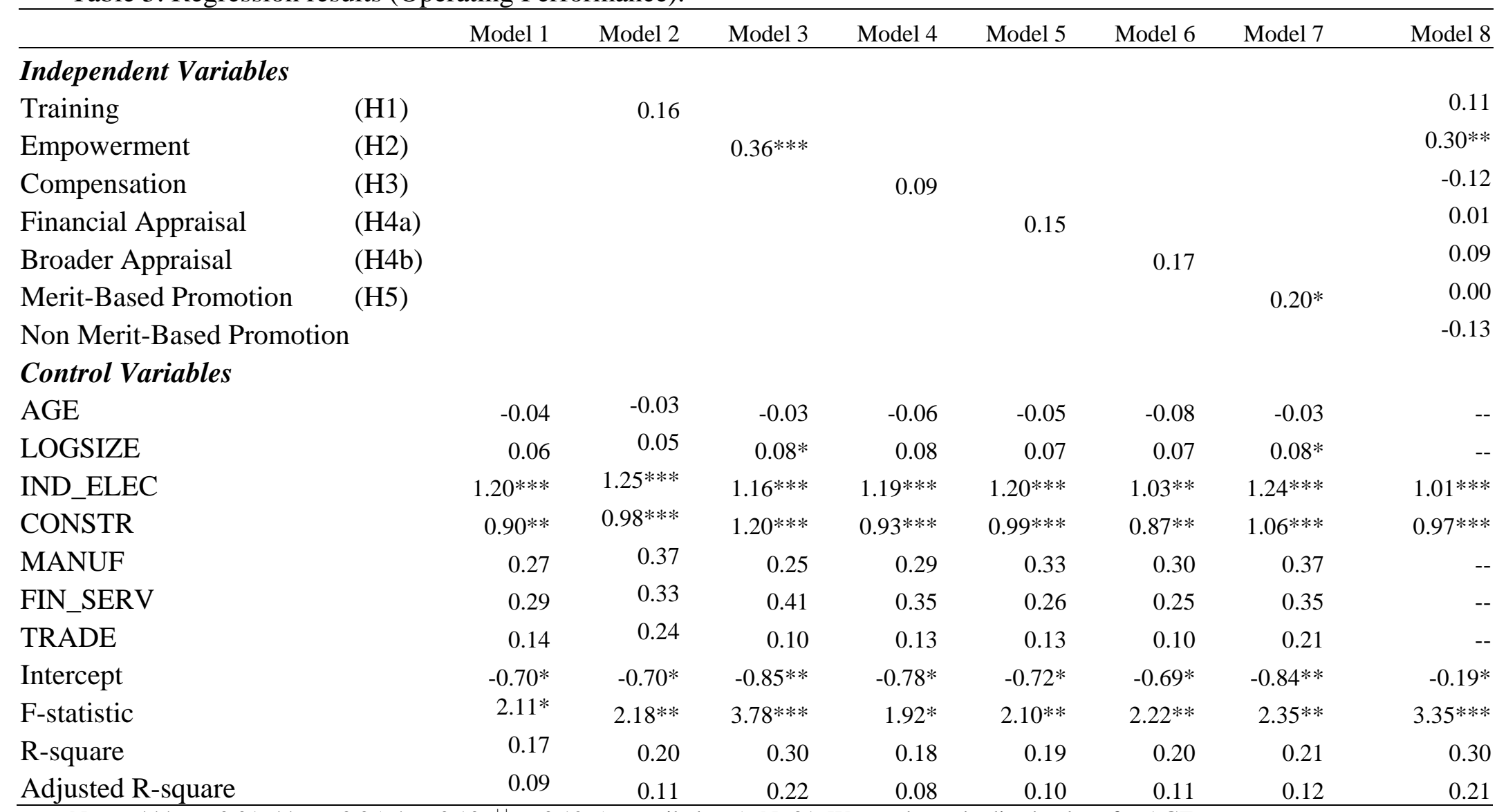

Notes: ${ }^{* * *} \mathrm{p}<0.01 ;{ }^{* *} \mathrm{p}<0.05 ;{ }^{*} \mathrm{p}<0.10 ;{ }^{++} \mathrm{p}<0.12$ (two-tailed test). $\mathrm{N}=81$. We used standardised values for AGE. 
Table 6. Regression results (Financial Performance).

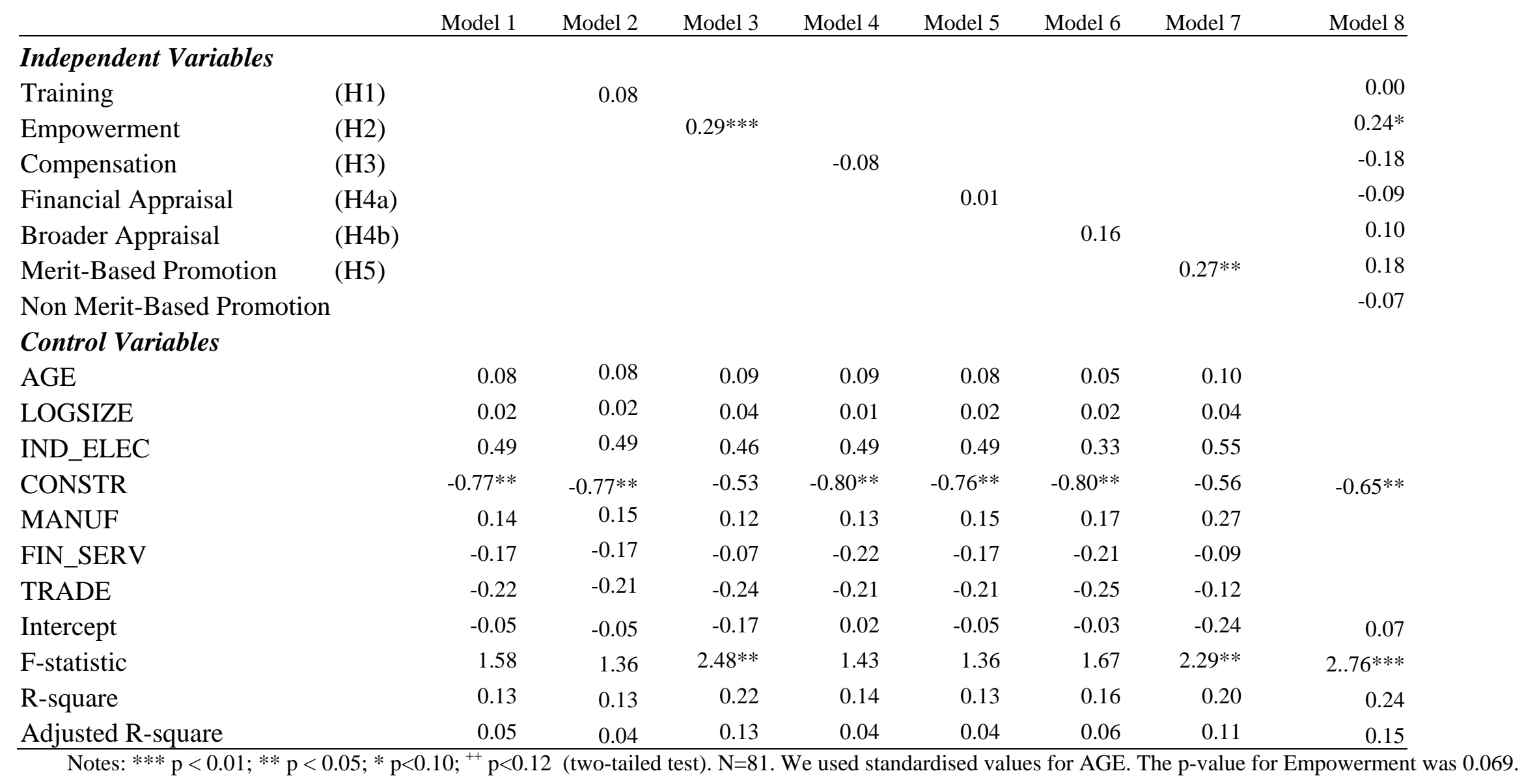


Table 7. Summary of Hypothesis Support.

\begin{tabular}{|l|c|c|}
\hline \multicolumn{1}{|c|}{ Hypothesis } & \multirow{2}{*}{ Business Performance } & \multicolumn{2}{c|}{ Financial Performance } \\
\cline { 3 - 4 } (H1) Training & Employee Performance & Operating Performance \\
\hline (H2) Empowerment & Accept & Reject (insignificant) \\
\hline (H3) Performance-based compensation & Accept & Accept \\
\hline (H4) Competence-based performance appraisal & Accept & Reject (insignificant) \\
\hline (H5) Merit-based Promotion & $\begin{array}{c}\text { Reject (partly significant but } \\
\text { positive) }\end{array}$ & Reject (insignificant) \\
\hline
\end{tabular}

